\title{
Editorial / Editor's note
}

A Revista Scientia Canonica é uma produção do Instituto Superior de Direito Canônico Santa Catarina (ISDCSC) com publicação semestral online e impressa e tem por finalidade o desenvolvimento da pesquisa em Direito Canônico com uma visão interdisciplinar. O primeiro número que apresentamos é composto por seis artigos que se articulam entre os temas de teologia e filosofia do direito, pastoral judiciária, família e Acordo Brasil-Santa Sé.

Tarcísio Pedro Vieira escreve sobre a Justiça na Igreja em sua compreensão teológico-jurídica. $\mathrm{O}$ artigo desenvolve o conceito filosófico e a perspectiva cristã de justiça, bem como o seu desenvolvimento na história eclesial e sua incidência na eclesiologia com a noção de potestas iudicialis. No entanto, o autor abre a justiça para o tema da misericórdia e da caridade, fazendo valer uma compreensão teológica do direito.

Um dos temas mais estudados contemporaneamente na literatura canônica é a reforma do processo matrimonial realizada pelo Papa Francisco. Valdinei de Jesus Ribeiro apresenta o artigo sobre a pastoral judiciária e o processo de nulidade matrimonial. Foram decisivos para tal reforma o Sínodo da Família e a Exortação Apostólica PósSinodal Amoris Laetitia que exigiram um novo discernimento da Pastoral Judiciária.

O terceiro artigo continua com o tema família faz referência ao modelo legal de família e às tendências atuais, articulando a reflexão jurídica canônica e civil. Frederico Martins e Silva fundamenta a relação da fé eclesial com o mundo, segundo as tendências da contemporaneidade, para uma abertura à reflexão sobre o conceito de família, considerando, no entanto, a visão do Magistério Eclesial.

O quarto artigo reúne as alocuções de João Paulo II ao Tribunal da Rota Romana, fornecendo uma ampla visão sobre a jurisprudência 
rotal como serviço à Igreja e à humanidade. Na verdade, as alocuções sintetizam uma teologia do direito que vai além de uma visão meramente organizativa da legislação eclesial, como instrumento para a legítima defesa das pessoas e do sacramento do matrimônio.

Em julho de 2017 foi promovido pelo ISDCSC o Seminário sobre o Acordo Brasil-Santa Sé. O restaurador Marcelino Donizeth de Melo Correia apresenta o tema sobre a Proteção dos bens culturais da Igreja. A finalidade da reflexão demonstra a influência do Catolicismo sobre os referenciais simbólicos na cultura brasileira e a necessidade da preservação por serem de fato objetos simbólicos.

Por fim, Magna Celi Mendes da Rocha repercute, a partir do pensamento de Edith Stein (Santa Teresa Benedita da Cruz, 18911943), a decisão do Supremo Tribunal Federal que rejeitou em 2017 o pedido da Procuradoria Geral da República que considerava inconstitucional o Acordo Brasil-Santa Sé. Na verdade, ao permitir o ensino confessional católico ou de outras confissões nas escolas públicas, na decisão do Supremo Tribunal Federal prevaleceu o entendimento de que o ensino religioso é uma decisiva contribuição para a formação integral da pessoa e faz parte da formação básica do cidadão brasileiro.

O ISDCSC está trabalhando para que a Revista Scientia Canonica seja um instrumento de pesquisa sobre a ciência canônica em diálogo com as diversas realidades culturais e eclesiais. Para tanto, estamos com as portas abertas para o diálogo com as ciências e sabemos que o Direito Canônico tem uma história milenar que não pode ser escondida dentro dos muros eclesiais. Pela Revista Scientia Canonica e pelo ISDCS (estudantes, professores e funcionários) a sociedade brasileira receberá uma grande riqueza cultural e humana a partir da ciência canônica. Em contrapartida, o Direito Canônico também se enriquece com as perspectivas culturais da sociedade contemporânea. Diálogo faz bem a todos e esse é o propósito da Revista Scientia Canonica. Boa leitura.

Denilson Geraldo Editor 